Al-Huquq: Journal of Indonesian Islamic Economic Law, 2 (1), 2020: 115 - 132

ISSN: 2715-0003; E-ISSN 2714-5514

DOI: http://dx.doi.org/10.19105/al-huquq.v1i2.3073

\title{
Sejarah Kodifikasi Hukum Ekonomi Syariah di Indonesia
}

\author{
Kudrat Abdillah, Yenny Susilawati \\ (Institut Agama Islam Negeri Madura, Jl. Raya Panglegur Km. 4 \\ Pamekasan)
}

\begin{abstract}
Abstrak:
Tulisan ini mengungkapkan sejarah kodifikasi hukum ekonomi syariah di Indonesia. Keluarnya Kompilasi Hukum Ekonomi Syariah dalam format Peraturan Mahkamah Agung Nomor 2 Tahun 2008 tidak lepas dari bertambahnya kewenangan Peradilan Agama dalam menangani perkara. Kewenangan Peradilan Agama tertuang dalam UndangUndang Peradilan Agama Nomor 3 Tahun 2006 menggantikan Undang-Undang Nomor 7 Tahun 1989. Dengan perubahan tersebut, kini Peradilan Agama berwenang menangani perkara-perkara ekonomi syariah, yang sebelumnya hanya menangani perkara di bidang keluarga Islam. Dengan menggunakan pendekatan sejarah, tulisan ini berusaha mengangkat sejarah perjalanan munculnya Kompilasi Hukum Ekonomi Syariah serta implikasinya. Hasilnya menunjukkan bahwa munculnya KHES merupakan jawaban atas perubahan kewenangan Peradilan Agama. KHES menjadi hasil pemikiran di bidang ekonomi Islam yang dikoordinir oleh Mahkamah Agung. Hadirnya KHES juga memberikan tiga kontribusi penting bagi perkembangan hukum di Indonesia. Pertama KHES menjadi pedoman dan pegangan hakim di Pengadilan Agama dalam memutuskan perkara ekonomi syariah. Kedua, KHES menjadi bukti hasil produk asli mujtahid di Indonesia dengan mempertimbangkan hukum Islam dan karakter keindonesiaan. Ketiga, KHES menunjukkan sisi fleksibilitas Hukum Islam dalam menghadapi perkembangan zaman. [This paper reveals the history of the codification of sharia economic law in Indonesia. The issuance of a Sharia Economic Law Compilation in the form of Supreme Court Regulation Number 2 of 2008 cannot be separated from the increased authority of the Religious Courts in handling cases.
\end{abstract}

https://creativecommons.org/licenses/by-nc/4.0/

Copyright (c) 2019 by al-huquq. All Right Reserved

Author Correspondence: kudrat.abdillah@iainmadura.ac.id 
The authority of the Religious Courts is contained in the Religious Courts Law Number 3 of 2006 replacing Law Number 7 of 1989. With this change, now the Religious Courts have the authority to handle sharia economic cases, which previously only handled cases in the field of Islamic families. By using a historical approach, this paper seeks to raise the history of the emergence of the Islamic Economic Law Compilation and its implications. The results show that the emergence of KHES is an answer to the change in the authority of the Religious Courts. KHES is the result of thoughts in the field of Islamic economics coordinated by the Supreme Court. The presence of KHES also provides three important contributions to the development of law in Indonesia. First, KHES becomes a guideline and guide for judges in the Religious Courts in deciding cases of sharia economy. Second, KHES is proof of the original product of the mujtahid in Indonesia by considering Islamic law and Indonesian character. Third, KHES shows the flexibility of Islamic law in facing the times.]

$$
\begin{gathered}
\text { Kata Kunci: } \\
\text { Sejarah; Kodifikasi; Hukum Ekonomi Syariah }
\end{gathered}
$$

\section{Pendahuluan}

Penerapan hukum ekonomi di Indonesia terdapat dalam tiga dimensi hukum, yaitu Hukum Islam, Hukum Adat, dan Hukum Positif. Hukum Islam secara masif dijalankan oleh umat Islam. Hukum adat secara turun temurun dilestarikan oleh masyarakat. Sedangkan hukum positif adalah hukum yang terkodifikasi dan disahkan oleh Dewan Perwakilan Rakyat sebagai lembaga yang berwenang, dalam bentuk Undang-Undang dan Peraturan Perundang-undangan, serta berlaku bagi seluruh warna Indonesia.

Hukum Islam yang dimaksud diatas lebih khusus pada hukum perkawinan (perkawinan, perceraian, kewarisan) dan hukum muamalat. ${ }^{1}$ Pada kenyataannya, penerapan hukum keluarga (Figh

1 Menurut Muhammad 'Ali at-Tahanawi, Syari'ah itu mencakup seluruh aspek ajaran Islam, meliputi aqidah, ibadah, akhlak, dan mu'amalat. Dalam Kitab Kisyaf Istilahat al-Funun, sebagaimana dikutip Ahmad Azhar 
Munakahat) dan hukum muamalat (Fiqh Muamalah) dalam masyarakat muslim Indonesia terdapat perbedaan: hukum keluarga itu memang telah dipraktekkan oleh umat Islam sejak lama dengan kesadarannya sendiri, sehingga telah menjadi bagian dari adat istiadat umat Islam. ${ }^{2}$ Sedangkan Fiqh muamalah, secara umum belum dipraktekkan dan belum menjadi adat-istiadat umat Islam. Fiqh muamalat secara kelembangaan hanya dipraktekkan lewat Lembaga Keuangan Syariah $^{3}$ yang secara hukum memang harus ada yang mengaturnya karena menyangkut hak-hak dan kepentingan banyak pihak dan dalam skala yang lebih besar. ${ }^{4}$ Kejelasan antar pihak terdapat pada akad yang mereka sepakati, sehingga bisa ditemukan solusinya. ${ }^{5}$

Jika dikaitkan dengan teori kodifikasi Prof Minhaji, ${ }^{6}$ negara hukum tidak bisa menerapkan dan menegakkan peraturan kecuali sudah terkodifikasi. Kodifikasi adalah segala aturan hukum yang telah disahkan oleh legislatif. Kodifikasi juga merupakan kumpulan peraturan-peraturan yang tersusun dalam bahasa undang-undang yang disahkan dan termasuk bagian dari hukum tertulis atau hukum positif. Kodifikasi sering diartikan sebagai upaya positifisasi, terutama Hukum Perdata Islam. ${ }^{7}$

Dalam konteks hukum, kita jarang mendengar istilah kompilasi, meskipun istilah kompilasi relatif mudah untuk dicari di kamus, ensiklopedia, atau buku terkait terminologi hukum, namun

Basyir. Lihat Ahmad Azhar Basyir, Asas-asas Hukum Muamalat, (Yogyakarta: Fakultas Hukum UII, 1988), hlm. 1.

2 Muhammad Daud Ali, Hukum Islam: Pengantar Ilmu Hukum dan Tata Hukum Islam di Indonesia, Cet. 3, (Jakarta: PT. Raja Grafindo Rosada, 1993), hlm. 201. Lihat M.B. Hoeker, Adat Law in Modern Indonesia, (Kuala Lumpur: Oxford University Press, 1978), hlm. 97.

3 Burhanuddin, Hukum Bisnis Syariah, (Yogyakarta: UII Press, 2011), hlm. 107.

4 Abdul Mughits, Kompilasi Hukum Ekonomi Syariah dalam Tinjauan Hukum Islam, Jurnal Al-Mawarid Edisi XVIII Tahun 2008, hlm. 142.

${ }^{5}$ Dwi Sutikno, Ayat-Ayat Ekonomi Islam, (Yogyakarta: Pustaka Pelajar, 2010), hlm. 66.

${ }^{6}$ Akh. Minhaji, Sejarah Sosial dalam Studi Islam: Teori, Metodologi, dan Implementasi, (Yogyakarta: SUKA Press, 2013), hlm. 64.

7 Pius A Partanto dan M Dahlan Albarry, Kamus Ilmiah Populer, (Surabaya: Arloka, 1994), hlm. 344. 
tidak ada penjelasan yang spesifik terkait pengertian kompilasi. Hal ini disebabkan karena minimnya penggunaan istilah tersebut dalam penerapanya. Kita akan lebih familiar dan lebih mengenal istilah kodifikasi dari pada kompilasi. ${ }^{8}$

Perbedaan antara kodifikasi/Kitab undang-undang dan undang-undang terletak pada materinya. Kodifikasi memliki materi yang luas tidak hanya satu sektor peraturan namun bisa mencakup seluruh bidang hukum dalam satu frame semisal Kitab Undangundang Hukum Pidana (KUHP) atau Kitab Undang-undang Hukum Perdata (KUHPdt). Sedangkan Undang-Undang hanya mencakup salah satu sektor dari hukum semisal UU No. 1 Tahun 1974 tentang Perkawinan. Dengan begitu, Kompilasi Hukum Ekonomi Syariah bisa kita rumuskan sebagai himpunan atau kumpulan atau ringkasan pendapat-pendapat hukum Islam yang disaring dari sumber-sumber kitab hukum (figh) tentang ekonomi syariah.

Selama ini bisa dipastikan semua materi Hukum Islam terdapat dalam kitab-kitab klasik (kitab kuning). Sementara jika ditegakkan pada negara hukum, ketika ada persinggungan antara hukum Islam dengan hukum positif, maka akan selalu diprioritaskan hukum positif, yang telah disahkan oleh negara.

Di Indonesia sudah banyak hukum-hukum Islam yang dikodifikasi ke dalam peraturan perundang-undangan seperti Undang-Undang Perkawinan No. 1 Tahun 1974, Kompilasi Hukum Islam dalam Inpres No. 1 Tahun 1991, Undang-Undang Wakaf No. 41 Tahun 2004, Undang-Undang Perbankan Syariah No. 21 Tahun 2008, dan lain sebagainya.

Kehadiran Kompilasi Hukum Ekonomi Syariah merupakan wujud respon disahkannya UU No. 3 Tahun 2006 Tentang Perubahan atas UU No. 7 Tahun 1989 Tentang Peradilan Agama (UUPA). UU No.3 Tahun 2006 menjadikan kewenangan Peradilan Agama menjadi luas. Bukan tanpa asalan, mengikuti perkembangan hukum kontemporer dan kebutuhan masyarakat muslim di Indonesia saat ini sangat diperlukan agar antara peraturan dan perkembangan selalu

8 S. Wojowasito dan WJS. Poerwadaminta, Kamus Lengkap Inggris Indonesia -Idonesia- Inggris, (Jakarta: Hasta, 1982), hal. 88. 
sejalan seirama. ${ }^{9}$ Kewenangan Peradilan Agama awalnya hanya menangani perkara di bidang perkawinan, waris, wasiat, hibah, wakaf, dan sadaqah. Dengan undang-undang yang baru Peradilan Agama juga berwenang menyelesaikan perkara permohonan pengangkatan anak (adopsi) dan menyelesaikan sengketa dalam zakat, infaq, serta sengketa hak milik dan keperdataan lainnya antara sesama muslim, dan ekonomi syari'ah. ${ }^{10}$

\section{Sejarah Penyusunan Kompilasi Hukum Ekonomi Syariah}

Kompilasi Hukum Ekonomi Syariah merupakan produk pemikiran akademisi Indonesia dalam bidang hukum ekonomi Islam yang terkodifikasi. Membutuhkan perjuangan panjang agar aturan ini disahkan dan dapat digunakan dalam sistem perundang-undangan. Sehingga permasalahan ekonomi syariah di Indonesia kini sudah mempunyai aturan baku dalam bentuk Peraturan Mahkamah Agung No. 2 Tahun 2008.

Disusunnya Perma No. 2 Tahun 2008 tentang Kompilasi hukum Ekonomi Syariah ini bermula dengan lahirnya UndangUndang Nomor: 3 Tahun 2006 tentang Perubahan Atas UndangUndang Nomor: 7 Tahun 1989 tentang Peradilan Agama. Perubahan ini memperluas ruang lingkup kewenangan Peradilan Agama dalam menangani sengketa, khususnya sengketa Ekonomi Syariah. Sehingga dampak lain jelas menggeser terhadap eksistensi dan kedudukan Peradilan Agama di Indonesia lebih maju. ${ }^{11}$

Semula Peradilan Agama diberi kewenangan menyelesaikan permasalahan-permasalahan Hukum Keluarga Islam. Namun kini sudah berwenang menangani dan menyelesaikan sengketa dalam bidang ekonomi syariah. Di antaranya meliputi perbankan syariah, lembaga keuangan mikro syariah, asuransi syariah, reasuransi syariah, reksadana syariah, obligasi syariah, dan surat berharga

\footnotetext{
${ }^{9}$ Shalah ash-Shawi dan Abdulloh al-Mushlih, Fikih Ekonomi Indonesia, (Jakarta: Darul Haq, 2015), hlm. 143.

10 Ramdlon Naning, Penyelesaian sengketa dalam Islam, Jurnal Varia Advokat, VI, Tahun 2008, hlm.29-30.

${ }^{11}$ Kompilasi Hukum Ekonomi Syariah, Peraturan Mahkamah Agung Republik Indonesia Nomor 2 Tahun 2008, (Jakarta: Ditjen Badilag Mahkamah Agung RI, 2013), hlm. 253.
} 
berjangka menengah syariah, sekuritas syariah, pembiayaan syariah, pegadaian syariah, dana pensiunan lembaga keuangan syariah, serta bisnis syariah.

Mahkamah Agung Republik Indonesia memutuskan kebijakan-kebijakan untuk realisasi perubahan kewenangan Peradilan Agama. Pertama, memperbaharui sarana- dan prasarana Lembaga Peradilan Agama, yang bersifat fisik gedung dan ruangan maupun fasilitas peralatan lain yang mendukung. Kedua, memaksimalkan pelatihan dan peningkatan Sumber Daya Manusia (SDM) Peradilan Agama dalam wujud bekerjasama dengan Perguruan Tinggi untuk mendidik para aparat Peradilan Agama, terutama para hakim dalam bidang ekonomi syariah. Ketiga, menyusun hukum (baik formil dan maupun materil) untuk dijadikan pedoman baku bagi aparat Peradilan Agama dalam memeriksa, mengadili, dan memutuskan perkara di bidang ekonomi syariah. Keempat, merekonstruksi prosedur dan sistem supaya sengketa perkara bidang ekonomi syariah dapat diselesaikan secara sederhana, mudah, dan berbiaya ringan. ${ }^{12}$

Dalam penyusunan draft hukum formil dan hukum materil ekonomi syariah, Ketua Mahkamah Agung RI membuat sebuah tim bernama tim Penyusunan Kompilasi Hukum Ekonomi Syariah. Keputusan pembentukan tim ini tertuang dalam KMA/097/SK/X/ 2006 tertanggal 20 Oktober 2006 dengan Ketua tim Prof. Dr. H. Abdul Manan, SH., S.IP, M.Hum.

Tim Penyusunan Kompilasi Hukum Ekonomi Syariah memiliki beberapa tugas penting. Pertama, menghimpun dan mengolah bahan/materi yang diperlukan tentang materi ekonomi syariah. Kedua, menyusun draft naskah Kompilasi Hukum Ekonomi Syariah. Ketiga, mengadakan kajian diskusi dan seminar yang mengkritisi draft naskah tersebut bersama lembaga, ulama, dan para pakar ekonomi syariah. Keempat, menyelaraskan naskah Kompilasi Hukum Ekonomi Syariah. Kelima, menyampaikan hasil penyusunan draft Kompilasi Hukum Ekonomi Syariah kepada Ketua Mahkamah Agung RI.

12 Dr. Mardani, Kedudukan Kompilasi Hukum Ekonomi Syariah di Indonesia, Jurnal Islamic Economics \& Finance (IEF) Universitas Trisakti, Tahun 2010, hlm. 7. 
Dalam pelaksanaannya, tim penyusun KHES membagi ke beberapa kelompok agar menghasilkan pemikiran yang terarah sesuai dengan tema. Pertama, Prof. Dr. H. Abdul Manan, SH, S.IP, M.Hum. yang mengkordinir kajian diskusi yang berhubungan dengan Perbankan Syariah. Kedua, kelompok Dr. H. Rifyal Ka'bah, MA. yang mengkaji hal-hal yang berkaitan dengan lembaga keuangan mikro syariah, obligasi dan surat-surat berharga syariah, reksadana syariah, dan pasar modal syariah. Kemudian kelompok ketiga dikoordinatori Dr. H. Abdurrahman, SH., MH. memfokuskan pada hal-hal yang berhubungan dengan asuransi dan reasuransi syariah, pergadaian syariah, dana pension, lembaga keuangan syariah, pembiayaan syariah, dan sekuritas syariah. Keempat, membahas hal-hal yang berhubungan dengan bisnis syariah dan hal-hal lain yang berhubungan dengan muamalah Islam dengan coordinator Drs. H. Habiburrahman, M.Hum.

Beberapa langkah praktis yang dilakukan oleh tim penyusunan Kompilasi Hukum Ekonomi Syariah adalah, Pertama, menyesuaikan pola pikir (united legal opinion). Pentingnya menyamakan persepsi dan pola pikir dalam penyusunan KHES ini, tim mengadakan seminar diskusi tentang ekonomi syariah di Hotel Sahid Kusuma Solo pada tanggal 21 s/d 23 April 2006 dan di Hotel Sahid Yogyakarta pada tanggal 4 s/d 6 Juni 2006. Kedua seminar tersebut dihadiri oleh para pakar ekonomi syariah, baik dari Perguruan Tinggi, Majelis Ulama Indonesia/Dewan Syariah Nasional, Badan Arbitrase Syariah Nasional (Basyarnas), dan para praktisi perbankan syariah (Bank Muamalat) serta para hakim baik dari lingkungan Peradilan Umum maupun dari Peradilan Agama. ${ }^{13}$

Kedua, Mencari format yang ideal (united legal frime work). Tim Penyusun Kompilasi Hukum Ekonomi Syariah mengadakan pertemuan dengan Bank Indonesia untuk mendapatkan masukan tentang segala hal yang berlaku pada Bank Indonesia terhadap ekonomi syariah. Selain itu juga sejauh mana pembinaan yang telah

${ }^{13}$ Abdul Mughits, Kompilasi Hukum Ekonomi Syariah dalam Tinjauan Hukum Islam, Jurnal Al-Mawarid Edisi XVIII Tahun 2008, hlm. 144. 
dilakukan oleh Bank Indonesia terhadap perbankan syariah di Indonesia. ${ }^{14}$

Kesempatan tersebut diselenggarakan di Hotel Bidakara Jakarta pada tanggal 7 Juni 2006. Tim Penyusun KHES juga menyelenggarakan Semiloka bertemakan Ekonomi Syariah di Hotel Grand Alia Cikini Jakarta pada tanggal 20 November 2006. Dalam Semiloka ini telah berbicara para pakar ekonomi syariah dari Bank Indonesia, Pusat Komunikasi Ekonomi Syariah (PKES), Majelis Ulama Indonesia (MUI), Ikatan Para Ahli Ekonomi Syariah, dan para praktisi hukum lain.

Langkah ketiga, melaksanakan kajian pustaka (Library Research). Berdasarkan pembagian kelompok sesuai tema masing-masing, semua kelompok melakukan kajian pada literatur kitab-kitab fiqh (kuning / klasik) dan literatur ekonomi kontemporer. Literaturliteratur tersebut tidak terbatas yang dipublikasikan oleh para pakar ekonomi syariah dan konvensional, baik dalam negeri maupun luar negeri.

Beberapa Kitab yang menjadi rujukan dalam proses penyusunan Kompilasi Hukum Ekonomi Syariah ini antara lain adalah:

1) Al-Figh al-Islami wa Adillatuh, karya Wahbah al-Zuhaili, Damas-kus: Dar al-Fikr. 2006, Cet ke-9.

2) Al-Fiqh al-Islami fi Tsaubihi al-Jadid, karya Mustafa Ahmad AlZarqa Damaskus: Dar al-Fikr. 2006, Cet ke-9.

3) Al-Mu'amalat al-Madiyah wa al-Adabiyah, karya Ali Fikri, Mesir, Mustafa al-babi al-Halabi. 1948.

4) Al-Wasith fi Syarh al-Qanun al-Madani al-Jadid, karya Abd. al- Razaq Ahmad al-Sanhuri, Beirut : Dar al-Ihya' al-Turats al-'Arabi.

5) Al-Muqaranat al-Tasyri'iyyah baina al-Qawanin al-Wadh'iyah alMadaniyah wa al-Tasyri al-Islami, karya Sayyid Abdullah Ali Husaini, Mesir: Dar al-Salam. 2001, cet. ke 1.

6) Durar al-Hukkam; Syarh Majallat al-Ahkam, karya Ali Haidar, Beirut: Dar al-Kitab al-Ilmiyah. 1991, cet. ke-1.

14 Ika Atikah, Eksistensi Kompilasi Hukum Ekonomi Syariah (KHES) sebagai Pedoman Hakim dalam Menyelesaikan Perkara Ekonomi Syariah di Pengadilan Agama, Jurnal Muamalatuna, 2017, hlm. 149. 
7) Himpunan Fatwa Dewan Syari'ah Nasional- MUI, Jakarta : DSNMUI dan Bank Indonesia. 2006, edisi revisi.

8) Peraturan Bank Indonesia tentang Perbankan Syari'ah.

9) PSAK (Pernyataan Standar Akuntansi Keuangan) Nomor 59 tanggal 1 Mei 2002 tentang Perbankan Syari'ah.

Tim Penyusunan Kompilasi Hukum Ekonomi Syariah juga menyelenggarakan studi banding ke Pusat Kajian Ekonomi Islam di Universitas Islam Internasional (UII) Kuala Lumpur, Pusat Takaful Malaysia Kuala Lumpur, Lembaga Keuangan Islam dan Lembaga Penyelesaian Sengketa Perbankan di Kuala Lumpur Malaysia. Kemudian studi banding ke Pusat Pengkajian Hukum Ekonomi Islam di Universitas Islam Internasional (UII) Islamabad, Federal Shariah Court Pakistan, Mizan Bank Islamabad Pakistan, Bank Islam Pakistan, serta beberapa institusi lembaga keuangan syariah yang ada di Islamabad Pakistan.

Studi banding juga dilakukan ke lembaga-lembaga ekonomi Islam di Inggris. Fokus studi banding ini untuk mendapatkan informasi mekanisme operasional/pelaksanaan lembaga keuangan Islam di Inggris, yaitu Islamic Bank of Britain di Whitehal London. Selain itu tim juga mengikuti training di Markfield Institute of Higher Education (MIHE), Leicester. Program ini secara khusus didesain agar bisa mengakomodasi keinginan delegasi Mahkamah Agung RI mendapat informasi yang mendalam berkaitan dengan pelaksanaan perbankan syari'ah di Inggris serta mekanisme penyelesaian sengketa/perkara (dispute settlement) yang terkait dengan perbankan syari'ah, baik melalui mediasi maupun pengadilan.

Selanjutnya seluruh kelompok melakukan presentasi hasil kajian dan studi banding sesuai dengan tema masing-masing. Kemudian dilakukanlah sinkronisasi antara satu bab dengan bab lainnya, sehingga akhirnya didiskusikan untuk mendapatkan masukan dari tim secara keseluruhan (pleno). Kegiatan ini dilaksanakan beberapa kali di tempat yang berbeda, yaitu di kampus Universitas Islam Negeri Sunan Gunung Djati Bandung, Tirtawening, di Ciburial, di Cipanas Garut, dan lainnya.

Kerja keras seluruh tim akhirnya menghasilkan draft Kompilasi Hukum Ekonomi Syari'ah (Academic Draft). Kemudian dilakukan kajian dan pembahasan bersama dengan tim konsultan dan 
dengan Mahkamah Agung RI. Kemudian Ketua Mahkamah Agung RI mengeluarkan Peraturan Mahkamah Agung RI (PERMA) No. 02 Tahun 2008 tentang Kompilasi Hukum Ekonomi Syari'ah.

Launching PERMA No. 02 Tahun 2008 dilakukan ketika RAKERNAS Mahkamah Agung bersama Para Ketua dan Panitera/Sekretaris Pengadilan Tingkat Banding dan Tingkat Pertama Seluruh Lingkungan Peradilan Seluruh Indonesia di Jakarta, bulan Agustus 2008. Atas isi KHES yang dilaunching tersebut, muncul kritik dan masukan perbaikan, baik menyangkut redaksi maupun substansi KHES, dari beberapa Ketua Pengadilan/Hakim Peradilan Agama. Setelah dilakukan beberapa perbaikan, dihasilkanlah Kompilasi Hukum Ekonomi Syariah yang berisi hukum materi tentang Subjek Hukum dan Amwal, Tentang Akad, Zakat dan Hibah, dan Akuntansi Syariah yang tertuang dalam 790 pasal. Secara sistematik Kompilasi Hukum Ekonomi Syariah (KHES) terbagi dalam 4 buku: Tentang Subjek Hukum dan Amwal, terdiri atas 3 bab (pasal 1-19), Tentang Akad terdiri dari 29 bab (pasal 20-673), Tentang Zakat dan Hibah yang terdiri atas 4 bab (pasal 674-734), dan tentang Akuntansi Syariah yang terdiri atas 7 bab (pasal 735-796).

Pada akhirnya, dengan disahkannya Kompilasi Hukum Ekonomi Syariah (PERMA No. 2 Tahun 2008) dapat dijadikan pedoman oleh para hakim di lingkungan Peradilan Agama dalam memeriksa, memutus, dan menyelesaikan perkara ekonomi syari'ah. Hal ini sekaligus menjadi jawaban atas kegelisahan para hakim atas perubahan kewenangan Peradilan Agama dalam menyelesaikan perkara ekonomi syariah.

\section{Kontribusi Kompilasi Hukum Ekonomi Syariah terhadap Perkembangan Hukum di Indonesia}

Kompilasi Hukum Ekonomi Syariah merupakan himpunan atau kumpulan atau ringkasan pendapat-pendapat hukum Islam yang disaring dari sumber-sumber kitab hukum (figh) tentang ekonomi syariah. ${ }^{15}$ KHES adalah upaya positifisasi hukum Islam ke

15 Pius A Partanto dan M Dahlan Albarry, Kamus Ilmiah Populer, (Surabaya: Arloka, 1994), hlm. 353. 
dalam hukum formal (hukum positif) di Indonesia. ${ }^{16}$ Hadirnya KHES ini dalam bentuk PERMA No. 2 Tahun 2008 memberikan kontribusi yang banyak terhadap perkembangan hukum Islam dan Hukum Positif di Indonesia.

1. Pedoman bagi Hakim Pengadilan Agama.

Selama ini aturan tentang hukum ekonomi syariah di Indonesia belum cukup diatur dalam peraturan perundangundangan. Menurut Agustianto, urgensi KHES dapat dilihat dari berbagai sisi. ${ }^{17}$ Pertama, rujukan hakim dalam memutus perkara ekonomi syariah yang belum ada sebagaimana terdapat dalam hukum perkawinan, warisan, wakaf, wasiat, dan hibah. Kedua, hukum fikih tentang aspek muamalah ini sangat beragam, apalagi persoalan muamalah ini adalah persoalan yang lebih terbuka bagi ijtihad, dibanding masalah ibadah. Oleh karena itu, diperlukan kepastian hukum, sehingga keputusan para hakim di berbagai pengadilan tidak berbeda-beda dalam kasus yang sama. Ketiga, Peraturan Bank Indonesia (PBI) sangat tidak memadai untuk dijadikan rujukan dalam memutus perkara ekonomi syariah, karena peraturan yang dikeluarkannya hanya berkaitan dengan masalah perbankan, sedangkan masalah hukum ekonomi syariah lainya tidak diatur, karena bukan wewenangnya. Demikian pula dengan fatwa - fatwa Dewan Syariah Nasional (DSN). Selain kedudukannya secara konstitusional tidak kuat dalam hierarki peraturan perundang - undangan di Indonesia, fatwa tersebut juga masih sangat ringkas, karena hanya berupa intisari yang membutuhkan penjelasan rinci.

Ketika wewenang mengadili sengketa hukum ekonomi syariah menjadi wewenang absolut hakim pengadilan agama, maka dibutuhkan adanya kodifikasi hukum ekonomi syariah yang lengkap agar hukum ekonomi syariah memiliki kepastian hukum dan para hakim memiliki rujukan standar dalam menyelesaikan kasus-kasus sengketa di dalam ekonomi syari'ah. Dalam bidang

16 A. Qadri Azizy, Eklektisisme Hukum Nasional, Kompetensi antara Hukum Islam dan Hukum Umum, cet. 1. (Yogyakarta: Gama Media, 2002), hlm. 172-173.

17 Agustianto, Urgensi Kodifikasi Hukum Ekonomi Syariah dalam http:// pesantrenvirtual.com 
perkawinan, warisan dan waqaf, kita telah memiliki Kompilasi Hukum Islam (KHI), sedangkan dalam bidang ekonomi syariah (Fiqh Muamalah) kita belum memilikinya.

Berkaca pada pengalaman sebelumnya, kedudukan KHI secara konstitusional masih sangat lemah, karena keberadaannya hanyalah sebagai Instruksi Presiden (inpres No. 1 Tahun 1991). Maka dari itu, dibutuhkan suatu aturan hukum yang lebih kuat yang dapat menjadi rujukan para hakim dalam memutuskan berbagai perkara di bidang hukum ekonomi syariah. Perumusan Kodifikasi Hukum Ekonomi Islam (Fiqh Muamalah) merupakan wujud konkret menjawab persoalan tersebut, sebagaimana yang dibuat pemerintahan Turki Usmani dengan nama Al-Majallah Al-Ahkam al-'Adliyah yang terdiri dari 1851 pasal. 18

Dalam pengambilan keputusan di Pengadilan dalam bidang ekonomi syariah dimungkinkan adanya perbedaan pendapat. Untuk itulah diperlukan adanya kepastian hukum sebagai dasar pengambilan keputusan di Pengadilan. Terlebih lagi dengan karakteristik bidang muamalah yang bersifat "elastis dan terbuka" sangat memungkinkan berfariasinya putusan-putusan tersebut nantinya yang sangat potensial dapat menghalangi pemenuhan rasa keadilan. Dengan demikian lahirnya Kodifikasi Hukum Ekonomi Syariah dalam sebuah Kitab-Undang-Undang Hukum Perdata Islam menjadi sebuah keniscayaan.

Sebagaimana dimaklumi bahwa formulasi materi Kodifikasi Hukum Ekonomi Syariah tidak terdapat dalam Yurisprudensi di lembaga-lembaga peradilan Indonesia. Meskipun demikian, yurisprudensi dalam kasus yang sama bisa dirujuk sepanjang tidak bertentangan dengan prinsip hukum ekonomi syariah. Artinya, keputusan hukum masa lampau itu difikihkan, karena dinilai sesuai dengan syariah. ${ }^{19}$

Hadirnya KHES menjadi satu solusi baru bagi para pencari keadilan di pengadilan agama dan memudahkan para hakim dalam mengupayakan putusan yang seadil- adilnya dalam

\footnotetext{
${ }^{18}$ Majallah al-Ahkam al-'Adliyyah, cet. 5 (Ttp: Ttp., t.t.).

${ }_{19}$ Abdullah Tri Wahyudi, Hukum Acara Peradilan Agama, (Bandung: CV. Mandar Maju, 2014), hlm. 21.
} 
menyelesaikan perkara ekonomi syariah yang masih sedikit peraturan hukum yang diatur sebagai hukum positif Indonesia. Meskipun keberadaannya hanya sebatas Peraturan Mahkamah Agung (PERMA), namun memiliki urgensi hukum yang mengikat bagi para hakim selain sumber - sumber hukum lain sebagai pedoman penyelesaian sengketa. Tak dapat dipungkiri, adanya KHES menjadi kodifikasi dan unifikasi dalam pembaharuan Hukum Ekonomi Syariah sehingga kebutuhan dalam hukum materiil maupun hukum formiil menjadi terpenuhi bagi para penegak hukum dan para pencari keadilan. Namun demikian, peran hakim dalam memutus perkara merupakan hal krusial sehingga ijtihad hakimlah sebagai penentu putusan Ex Aequo et Bono.

2. Merupakan produk ijtihad kolektif pemikir Islam di Indonesia.

KHES adalah produk asli pemikiran Para Mujtahid ekonomi dan ekonomi syariah yang berkarakter keislaman dan keindonesiaan. Para mujtahid ekonomi syariah Indonesia, bukan saja merumuskan hukum ekonomi baru yang berasal dari normanorma fikih/syariah, tetapi bagaimana bisa memfikihkan hukum nasional yang telah ada. Hukum nasional yang bersumber dari KUH Perdata (BW), kemungkinan besar banyak yang sesuai syariah, maka materi dan keputusan hukumnya dalam bentuk yurusprudensi bisa ditaqrir atau diadopsi.

KUH Perdata (BW) yang mengambil masukan dari Code Civil Perancis ini dalam pembuatannya mengambil pemikiran para pakar hukum Islam dari Mesir yang bermazhab Maliki, sehingga tidak aneh apabila terdapat banyak kesamaan prinsip-prinsip dalam KUH Perdata dengan ketentuan fikih Muamalah tersebut, seperti hibah, wadi' ah dan lain-lain.

Selain itu, yurisprudensi putusan ekonomi syariah, mungkin juga bisa dicari dari penerapan hukum adat di dalam putusan pengadilan yang ada di negara kita yang sedikit banyak telah diinspirasikan oleh ketentuan hukum Islam. Yang paling bagus adalah merujuk Kitab Undang-Undang Hukum Perdata Islam yang pernah dibuat di zaman Kekhalifahan Turki Usmani yang disebut Majalah Al-Ahkam Al-Adliyah" KUH Perdata Islam ini dapat dikembangkan dan diperluas bahasannya disesuaikan 
dengan perkembangan aktivitas perekonomian di zaman modern ini.

Selain itu, penyusunan Kodifikasi Hukum Ekonomi Syariah atau Hukum Perdata Islam, harus menggunakan ilmu ushul fiqh dan qawa'id fiqh. Disiplin ini adalah metodologi yurispridensi Islam yang mutlak diperlukan para mujtahid. Dengan demikian maqashid syariah perlu menjadi landasan perumusan hukum. Metode istihsan, urf, sadd zariah, dan pertimbanganpertimbangan 'kemaslahatan' menjadi penting. Dengan demikian, diharapkan, selain akan dapat memelihara dan menampung aspirasi hukum serta keadilan masyarakat, Kodifikasi Hukum Ekonomi Syariah juga akan mampu berperan sebagai perekayasa (social enginaring) masyarakat muslim Indonesia.

Secara teoritis penerapan Kodifikasi Hukum Ekonomi Syariah di Indonesia ini dapat terwujud melalui peran penting pemerintah 'Political Will' Penguasa, sebagaimana telah diterapkan pada Kompilasi Hukum Islam yang ada sekarang ini. Untuk menyusun Kodifikasi Hukum Ekonomi Syariah, peran Ikatan Ahli Ekonomi Islam (IAEI) sangat penting, mengingat IAEI adalah kumpulan para pakar ekonomi syariah Indonesia dari berbagai perguruan tinggi terkemuka.

Terlepas dari itu semua, norma hukum Islam menghendaki pemberlakuan hukum oleh setiap pemeluknya. Masalah bagaimana cara pemberlakuannya, hal itu kembali kepada metode pendekatannya, karena metode inilah yang akan membedakan antara satu ilmu dengan yang lainnya, meskipun obyeknya sama. ${ }^{20}$ Jika dilacak dari segi materi hukumnya, maka Hukum ekonomi syariah terus mengalami pengayaan, dari zaman Rasulullah SAW. sahabat, tabi'in, dan era Imam Mazhab hingga sekarang. Lebih jauh mencermati, materi hukum ekonomi syariah tidak terlepas dari semakin banyaknya metode yang muncul dalam memahami teks-teks nash al-Qur'an maupun as-Sunnah. ${ }^{21}$

20 Syamsul Anwar, Pengembangan Metode Penelitian Hukum Islam dalam Ainurrofiq (ed.), "Mazhab" Jogja, Mengagas Paradigma Usul Figh Kontemporer. Cet. 1, (Yogyakarta: Penerbit ar-Ruzz Press, 2002), hlm. 152.

21 Mohammad Mufid, Ushul Fiqh Ekonomi dan Keuangan Kontemporer: Dari Teori ke Aplikasi, (Jakarta: Kencana, 2016), hlm. 202. 
Melacak sejarahnya keluarnya KHES, banyak sekali pihakpihak yang dilibatkan untuk menyusun dan membahasnya, sehingga KHES merupakan produk ijtihad jama'i (kolektif/bersama). Pihak-pihak yang terlibat ialah para praktisi hukum (hakim agung), akademisi, ulama-ulama (MUI), dan para praktisi perbankan syariah. Ijtihad Jama'i ini memang tidak mengharuskan semua orang harus menguasai persyaratan sebagai mujtahid, tetapi cukup dengan memberikan kontribusi sesuai dengan bidangnya masing-masing. Hakim Agama, dalam kajian hukum Islam termasuk kategori mujtahid karena setiap keputusannya yang selalu mencerminkan hasil dari kegiatan ijtihadnya dan sah secara Syar'i karena sifatnya yang memaksa dan mengikat semua pihak yang berperkara. Artinya, jika dalam penyusunan KHES itu melibatkan para hakim agama maka hal itu dapat disebut sebagai hasil ijtihad. ${ }^{22}$

3. Menunjukkan sisi fleksibilitas Hukum Islam terhadap perkembangan zaman.

Kompilasi Hukum Ekonomi Syariah adalah Fiqh Muamalah yang dipositifisasi (dikodifikasi) ke dalam peraturan perundang-undangan dengan bahasa hukum. Hal ini merupakan satu pembaharuan dalam hukum Islam, karena selama ini materi figh muamalah hanya terdapat dalam kitab-kitab fiqh klasik.

Pengembangan suatu ilmu sudah tentu memerlukan proses pengkajian atas berbagai hal yang bersangkutan dengan ilmu itu sendiri maupun hal-hal lain yang berhubungan dengannya. Sama halnya dengan Fiqh, ${ }^{23}$ kata al-Figh berarti pemahaman. ${ }^{24}$ Fiqih adalah ilmu, oleh karena itu fiqh mempunyai tema pokok dengan kaidah-kaidah dan prinsip-prinsip khusus. Para fuqaha' pun

${ }^{22}$ Yusuf Qaradhawi, Ijtihad Kontemporer, Kode Etik, dan Berbagai Penyimpangan, alih bahasa oleh Abu Barzani, (Surabaya: Risalah Gusti, 1995), hlm. 15.

${ }^{23}$ Mun'im A. Sirry, Sejarah Fiqih Islam: Sebuah Pengantar, (Surabaya: Risalah Gusti, 1995), hlm. vii.

24 Ibid., hlm. 12. 
mempergunakan metode-metode tertentu dalam memahami sebuah nash, seperti qiyās, istiḥsān, istiṣhāab, dan lain-lain. ${ }^{25}$

Kitab-kitab fiqh yang telah dipakai di zaman sekarang tidak lain bermuara pada beberapa sumber, seperti al-Qur'an, asSunnah, dan ijtihad para Ulama. Hasil dari ijtihad para Ulama tidak akan terlepas dari situasi dan kondisi yang ada di sekitar ulama tersebut berada. Dari sini lah dapat terlihat bahwa hasil ijtihad tidak bersifat universal dan tidak berlaku sepanjang zaman, karena penetapan suatu hukum pasti akan didasarkan pada pertimbangan kemaslahatan pada masa Ulama menetapkan sebuah hukum.

Perubahan hukum yang disebabkan oleh berubahnya waktu, tempat, dan keadaan, tidak akan dapat dipungkiri karena kebutuhan hukum yang baru akan sangat dibutuhkan di tengahtengah masyarakat yang baru pula. Perubahan yang terjadi tidak lain bertujuan untuk menjawab kebutuhan-kebutuhan masyarakat di masanya. Perubahan hukum akan terus terjadi seiring perkembangan zaman dan seiring berubahnya sebuah adat ('urf), waktu, dan keadaan dll. Perubahan hukum yang dimaksud bukanlah perubahan secara tekstual melainkan secara kontekstual. Pendapat ini dapat dipahami dari kaidah fiqh yang berbunyi:

$$
\text { تغير الاحكام بتغير الازمنة و الامكنة و الاحو ال }
$$

Kaidah ini menunjukkan sebuah hukum bisa berubah dengan adanya perubahan waktu, tempat, dan keadaan. Saat ini KHES menjadi jawaban dan kebutuhan umat Islam, dalam bidang ekonomi syariah. KHES ada untuk menjaga kemashlahatan umat banyak, karena menyangkut banyak pihak.

Sebagaimana teori Anglo Saxon. Dalam hukum Islam dikenal teori 'urf atau adat, sebagai salah satu metode istinbat hukum. Dalam teori ini hukum dirumuskan dengan mempertimbangkan adat istiadat masyarakat. Sehingga dalam kajian istinbat hukum Islam dikenal kaidah, "perubahan hukum

\footnotetext{
25 Ibid., hlm. 15.

26 Muslih Usman, Kaidah-Kaidah Ushuliyah dan Fiqhiyyah, (Jakarta: Rajawali Press, 1996), hlm. 195.
} 
itu (ditentukan) oleh perubahan waktu, tempat, dan adat-istiadat. ${ }^{27}$ Terlebih bahasan tentang ekonomi syariah berhubungan dengan masyarakat secara langsung yang tak lepas dari dimensi sosiologis. Nabi Muhammad SAW., sudah jauh memberi aba-aba bahwa sifat hukum ekonomi syariah itu dinamis dan terbuka. ${ }^{28}$ Kaitannya dengan fleksibilitas dalam hukum ekonomi syariah dikenal kaidahdengan substansi bahwa semua akad ekonomi syariah (muamalat) mutlak diperbolehkan hingga ada hukum yang melarangnya. ${ }^{29}$

\section{Kesimpulan}

Tulisan ini mengungkapkan sejarah kodifikasi hukum ekonomi syariah di Indonesia. Keluarnya Kompilasi Hukum Ekonomi Syariah dalam format Peraturan Mahkamah Agung Nomor 2 Tahun 2008 tidak lepas dari bertambahnya kewenangan Peradilan Agama dalam menangani perkara. Kewenangan Peradilan Agama tertuang dalam Undang-Undang Peradilan Agama Nomor 3 Tahun 2006 menggantikan Undang-Undang Nomor 7 Tahun 1989. Dengan perubahan tersebut, kini Peradilan Agama berwenang menangani perkara-perkara ekonomi syariah, yang sebelumnya hanya menangani perkara di bidang keluarga Islam.

Hasilnya menunjukkan bahwa munculnya KHES merupakan jawaban atas perubahan kewenangan Peradilan Agama. KHES menjadi hasil pemikiran di bidang ekonomi Islam yang dikoordinir oleh Mahkamah Agung. Hadirnya KHES juga memberikan tiga kontribusi penting bagi perkembangan hukum di Indonesia. Pertama KHES menjadi pedoman dan pegangan hakim di Pengadilan Agama dalam memutuskan perkara ekonomi syariah. Kedua, KHES menjadi bukti hasil produk asli mujtahid di Indonesia dengan mempertimbangkan hukum Islam dan karakter keindonesiaan.

27 Ibn al-Qayyim al-Jauziyyah, I'lam al-Muwaqqi'in 'an Rabb al'Alamin, (Beirut: Dar al-Jail. III: 14, 1973), hlm. 14. Lihat Nasrun Rusli, Konsep Ijtihad asy-Syaukani, Relevansinya bagi Perubahan Hukum Islam di Indonesia, (Ciputat: PT. Logos Wacana Ilmu, 1999), hlm. 101.

${ }^{28}$ Imam Muslim, Sahih Muslim Syarh An-Nawawi, Juz XV, (Mesir: AlMatba' ah Al-Misriyyah wa Maktabatuha, 1934), hlm. 18.

${ }^{29}$ Wahbah az-Zuhaili,Ushul Al-Figh Al-Islami, Juz II, (Damaskus: AlMatba'ah al- 'Ilmiyyah, t.t), hlm. 810. 
Ketiga, KHES menunjukkan sisi fleksibilitas Hukum Islam dalam menghadapi perkembangan zaman.

\section{Daftar Pustaka}

Agustianto, Urgensi Kodifikasi Hukum Ekonomi Syariah dalam http:// pesantrenvirtual.com

Ali, Muhammad Daud, Hukum Islam: Pengantar Ilmu Hukum dan Tata Hukum Islam di Indonesia, Cet. 3, Jakarta, PT. Raja Grafindo Rosada, 1993.

Al-Jauziyyah, Ibn al-Qayyim, I'lam al-Muwaqqi'in 'an Rabb al-'Alamin, Beirut: Dar al-Jail. III, 14, 1973.

Anwar, Syamsul, Pengembangan Metode Penelitian Hukum Islam dalam Ainurrofiq (ed.), "Mazhab" Jogja, Mengagas Paradigma Usul Figh Kontemporer. Cet. 1, Yogyakarta, Penerbit ar-Ruzz Press, 2002.

Ash-Shawi, Shalah dan Abdulloh al-Mushlih, Fikih Ekonomi Indonesia, Jakarta, Darul Haq, 2015.

Atikah, Ika, Eksistensi Kompilasi Hukum Ekonomi Syariah (KHES) sebagai Pedoman Hakim dalam Menyelesaikan Perkara Ekonomi Syariah di Pengadilan Agama, Jurnal Muamalatuna, 2017.

Azizy, A. Qadri, Eklektisisme Hukum Nasional, Kompetensi antara Hukum Islam dan Hukum Umum, cet. 1,Yogyakarta, Gama Media, 2002.

Az-Zuhaili, Wahbah , Ushul Al-Figh Al-Islami, Juz II, Damaskus, AlMatba' ah al- 'Ilmiyyah, t.t.

Basyir, Ahmad Azhar, Asas-asas Hukum Muamalat, Yogyakarta, Fakultas Hukum UII, 1988.

Burhanuddin, Hukum Bisnis Syariah, Yogyakarta, UII Press, 2011.

Hoeker, M.B., Adat Law in Modern Indonesia, Kuala Lumpur, Oxford University Press, 1978.

Mahkamah Agung RI, Kompilasi Hukum Ekonomi Syariah: Peraturan Mahkamah Agung Republik Indonesia Nomor 2 Tahun 2008, Jakarta, Ditjen Badilag Mahkamah Agung RI, 2013.

Majallah al-Ahkam al-'Adliyyah, cet. 5 (Ttp: Ttp., t.t.).

Mardani, Kedudukan Kompilasi Hukum Ekonomi Syariah di Indonesia, Jurnal Islamic Economics \& Finance (IEF) Universitas Trisakti, Tahun 2010. 
Minhaji, Akh., Sejarah Sosial dalam Studi Islam: Teori, Metodologi, dan Implementasi, Yogyakarta, SUKA Press, 2013.

Mufid, Mohammad, Ushul Fiqh Ekonomi dan Keuangan Kontemporer: Dari Teori ke Aplikasi, Jakarta, Kencana, 2016.

Mughits, Abdul, Kompilasi Hukum Ekonomi Syariah dalam Tinjauan Hukum Islam, Jurnal Al-Mawarid Edisi XVIII Tahun 2008.

Mun'im A. Sirry, Sejarah Fiqih Islam: Sebuah Pengantar, Surabaya, Risalah Gusti, 1995.

Muslim, Ima,m Sahih Muslim Syarh An-Nawawi, Juz XV, Mesir, AlMatba'ah Al-Misriyyah wa Maktabatuha, 1934.

Naning, Ramdlon, Penyelesaian sengketa dalam Islam, Jurnal Varia Advokat, VI, Tahun 2008.

Partanto, Pius A dan M Dahlan Albarry, Kamus Ilmiah Populer, Surabaya, Arloka, 1994.

Qaradhawi, Yusuf, Ijtihad Kontemporer, Kode Etik, dan Berbagai Penyimpangan, alih bahasa oleh Abu Barzani, Surabaya, Risalah Gusti, 1995.

Rusli, Nasrun, Konsep Ijtihad asy-Syaukani, Relevansinya bagi Perubahan Hukum Islam di Indonesia, Ciputat, PT. Logos Wacana Ilmu, 1999.

Sutikno, Dwi, Ayat-Ayat Ekonomi Islam, Yogyakarta, Pustaka Pelajar, 2010.

Usman, Muslih, Kaidah-Kaidah Ushuliyah dan Fiqhiyyah, Jakarta Rajawali Press, 1996.

Wahyudi, Abdullah Tri, Hukum Acara Peradilan Agama, Bandung CV. Mandar Maju, 2014.

Wojowasito, S. dan WJS. Poerwadaminta, Kamus Lengkap InggrisIndonesia dan Indonesia-Inggris, Jakarta: Hasta, 1982. 